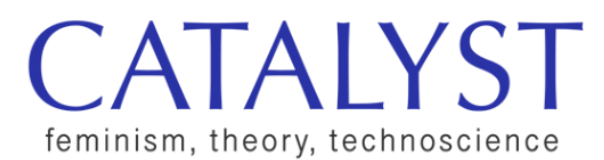

\title{
Book Review | A Future History of Water, by Andrea Ballestero (Duke University Press, 2019)
}

Kelsey Kim

UCLA

kelseyckim@ucla.edu

Water is indisputably essential to human life. Yet it was only in 2010 when water was declared a human right in the international sphere through the United Nation's Resolution 64/292. In A Future History of Water, Andrea Ballestero explores water's transition from commodity to human right by asking, what does water as a human right look like in capitalist societies, and how does price affect accessibility? Through her fieldwork in both Costa Rica and Brazil, two countries that have not fully incorporated the right to water into their constitutions, she examines how bureaucratic decisions impact access to water for thousands of people. For Ballestero, water is much more than what comes from a tap. Rather, it includes all the people and processes that inform decisions about water, including activists shaking empty water bottles filled with coins to protest the commodification of water; bureaucrats in offices making decisions that affect household access to water; and pacts between citizens and state officials promising to care for water. By examining the everyday work and decisions that imbue water with value, she considers the possible futures of water as its status and accessibility is negotiated and renegotiated between various actors and technolegal devices. These devices, through "larger processes of water price setting, legal reform, or the promotion of care for water," are used to determine water's worth (p. 8); they also frame Ballestero's ethnography, as each chapter is dedicated to a different device: Formula, Index, List, and Pact.

Kelsey Kim. (2020). Review of A Future History of Water, by Andrea Ballestero (Duke University Press), Catalyst: Feminism, Theory, Technoscience, 6(1), p. 1-3. 
The first chapter looks to how the market prices of water are determined in Cocles, Costa Rica, through the use of a formula. This formula was created by ARESEP (Autoridad Reguladora de los Servicios Públicos), the public services regulation authority responsible for regulating water costs; with the help of a community association, they track water consumption levels and run them through the formula to produce the monthly water bill. Rather than focusing on residents' experiences with water accessibility, Ballestero makes a conscious effort to show readers the bureaucratic labor of making water accessible. As water utility services are prohibited by law from making a profit, the water bill can only recoup operation costs. Yet deciding the recuperation of these costs is somewhat flexible and open to regulators' interpretation; therefore, regulators can tweak the formula to reflect their humanitarian obligation to make water more affordable.

The second chapter looks to the consumer price index (CPI) in deciding the cost of water in Costa Rica in relation to other household goods. Using the international benchmark that water should cost no more than $3 \%$ of the monthly household income, regulators utilize a CPI-an index of common household items and services and their prices, from cable to groceries to clothing-to adjust inflation rates by comparing these costs to the cost of water. Ballestero reflects on how the CPI has changed over the years-not only are items frequently added and omitted as regulators strive to reflect the average contemporary household, the CPI itself has undergone several name changes as well. For example, known as the cost of life index in the 1930s, its current name, consumer price index, now reflects an unmarked consumer. Ballestero notes the irony of regulators utilizing the $\mathrm{CPI}$ as part of their humanitarian efforts to make water more affordable, as the index now puts consumption at the forefront, defining the household instead by the most commonly purchased goods and services. In other words, "objects push humans to the background" as regulators attempt to fulfill their humanitarian obligations to make water more affordable (p. 99).

Chapter 3 examines how a list defining water's materiality is used to curtail Costa Rica's constitutional reform efforts to include water as a human right and public good. Arguing that water as a public good leads to exploitation, the Libertarian Party has compiled and employed a taxonomy of thirty-one types of water, from rain to laundry water to ice cubes, to question who would own water if it were to become a public good. They pose the question, for example, that if our bodies are $70 \%$ water, can they be owned by the government? In doing so, the Libertarian Party pushes back on attempts to give new meanings to water, effectively slowing 
down efforts of constitutional reform.

The fourth technolegal device and chapter, "Pact," shows readers the process of creating a promise to care for water in Ceará, Brazil. Concerned residents, state regulators, non-profit directors, and a mix of other public and private interest groups all gather at weekly public meetings to uphold and commit to a pact for shared responsibility of water. Rather than creating an enforceable, legally binding agreement, this pact is meant to be a collaborative process-a living agreement-to break Brazil's legacy of the coronelismo, or the local elites who, until the 1990 s reform, controlled and privatized water access. Diverging from the other three devices, this chapter highlights the collaborative process between citizens, the state, and other actors in creating a sense of shared responsibility and equal access. However, because the pact is meant to do many things at once (a public pledge to solve climate change, pollution, and scarcity, etc.), it has over time become more difficult to track what has actually been achieved, or designate who is responsible for fulfilling these promises. But throughout the disarray of collaboration in creating this living agreement, the pact has also opened up endless possibilities for the future of water.

Throughout her ethnography, Ballestero emphasizes the messiness and oftentimes mundane work it takes to make access to water a human right within capitalist society. She implores us to expand our conception of water to include this everyday work, which ultimately informs decisions regarding water for countless households. Ballestero also highlights the uncertainty and precariousness in creating possible futures for water-that despite working towards an imagined future for water, neither regulators nor involved residents know what this future holds. But despite this uncertainty, A Future History of Water showcases how everyday technolegal devices perform the essential work of creating a future in which water is accessible to all.

\section{Author Bio}

Kelsey Kim is a PhD candidate in anthropology at UCLA. Her research focuses on tech activism in Silicon Valley. 